4. Brayton-Cycle Heat-Recovery-System Characterization Program

\title{
GAS-CONDITIONING FINAL EVALUATION REPORT
}

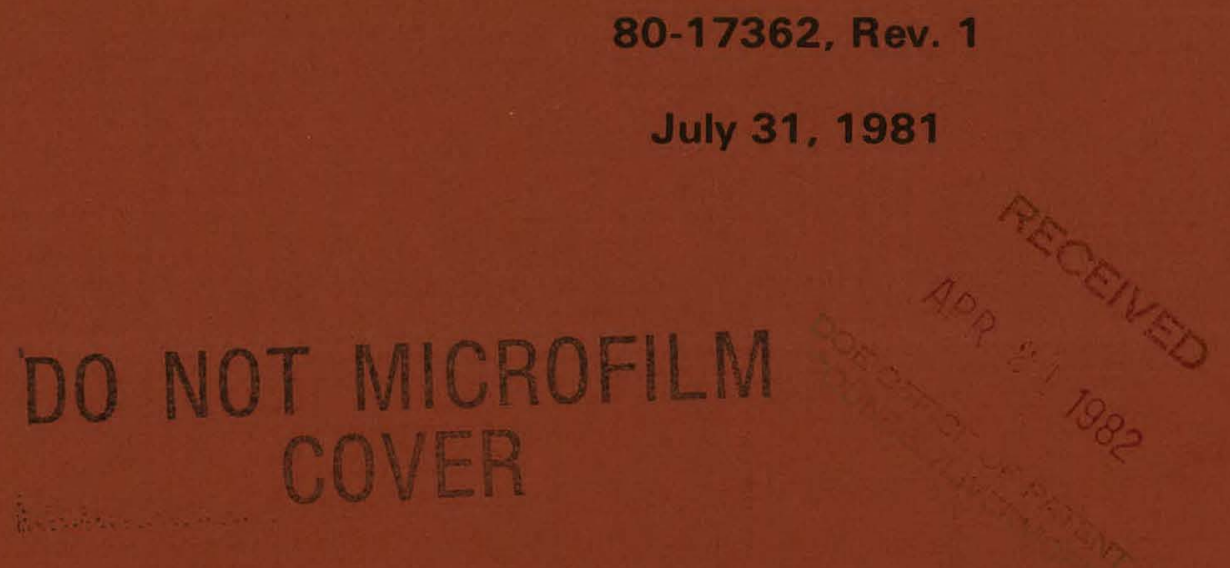

Prepared for

The Department of Energy

Contract No. EC-77-C-03-1557

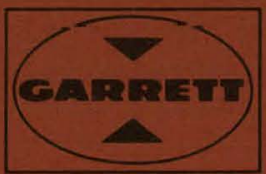




\section{DISCLAIMER}

This report was prepared as an account of work sponsored by an agency of the United States Government. Neither the United States Government nor any agency Thereof, nor any of their employees, makes any warranty, express or implied, or assumes any legal liability or responsibility for the accuracy, completeness, or usefulness of any information, apparatus, product, or process disclosed, or represents that its use would not infringe privately owned rights. Reference herein to any specific commercial product, process, or service by trade name, trademark, manufacturer, or otherwise does not necessarily constitute or imply its endorsement, recommendation, or favoring by the United States Government or any agency thereof. The views and opinions of authors expressed herein do not necessarily state or reflect those of the United States Government or any agency thereof. 


\section{DISCLAIMER}

Portions of this document may be illegible in electronic image products. Images are produced from the best available original document. 
$\mathrm{DOE} / \mathrm{CS} / 40008--\mathrm{T} 10$

DE82 008645

\section{Brayton-Cycle Heat-Recovery-System Characterization Program}

\section{GAS-CONDITIONING FINAL EVALUATION REPORT}

80-17362, Rev. 1

July 31, 1981

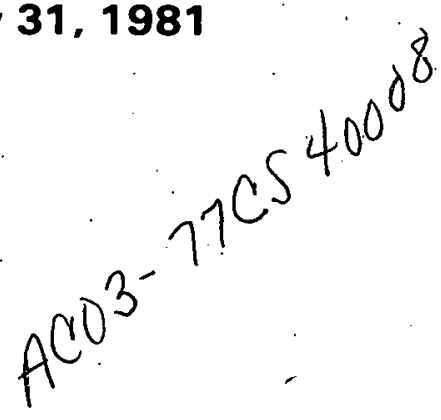

Prepared for

The Department of Energy

Contract No. EC-77-C-03-1557

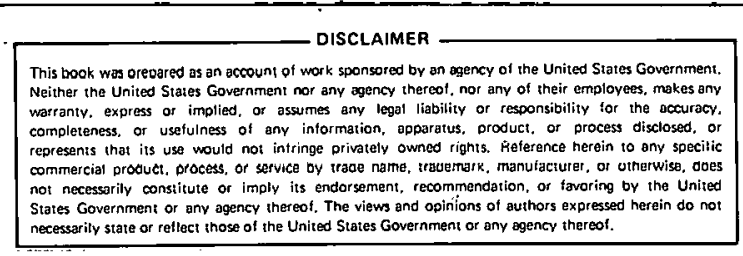

necessarily state or rellect those of the United States Government or any agency thereal.

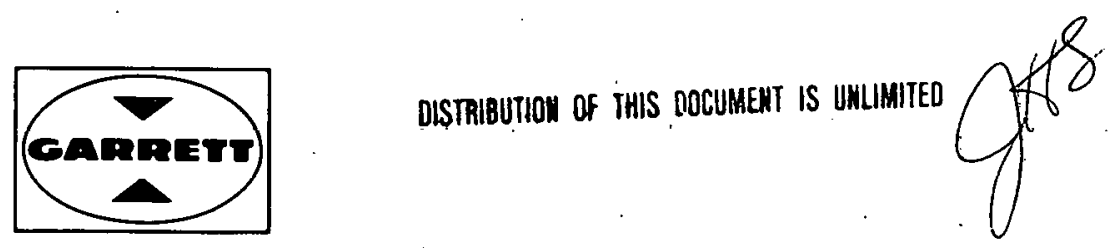




\section{CONTENTS}

Section

Page

1. GAS CONDITIONING EVALUATION

$1-1$

1.1 Erosion

1.2 Deposition

1.3 Conclusions

$1-2$

$1-3$

$1-5$

2. PARTICLE REMOVAL DEVICES

2-1

2.1 Cyclones

2.2 Granular Bed Filters

$2-2$

2.3 Surface Filters

2-4

2.4 Electrostatic Precipitators

$2-9$

2.5 Other Devices

$2-12$

2-14

3.

REFERENCES

$3-1$ 


\section{GAS CONDITIONING EVALUATION}

This topical report discusses flue gas conditioning approaches for the Brayton-cycle heat recovery system. The work described was conducted under program subtasks G2.1, G2.2, and G2.3 of the program plan (Reference 1).* This final report is a revision of the preliminary report dated September 17, 1980 and incorporates the results of recent AiResearch tests on the subatmospheric system (SAS) turbocompressor, as well as the Electric Power Research Institute sponsored tests on ceramic fiber filters.

The two primary purposes of the gas conditioning evaluation are:

- To determine the need for protecting the Brayton-cycle turbocompressor and heat exchanger from the potential damaging effects of erosion and deposition.

- To determine what type of approach should be used for cleanup, if protection by flue gas conditioning is required.

The evaluation of the possible detrimental effects of flue gas contaminants is based on: (1) the probable physical/chemical composition of the glass furnace flue gases (as characterized in Reference 2); and (2) the results of the SAS tests.

The work associated with utilizing coal for electrical power generation provides a major source of data and information on gas conditioning for gas turbine applications. In pressurized, fluidized-bed combustion (PFBC) of coal for power generation, two or three stages of cyclone-type particle separation are utilized for prefiltering. Additional filtering of particles smaller than $3 \mu \mathrm{m}$ in diameter, if necessary, is accomplished by other means. In the glass furnace, the checkers serve as highly effective filters that are comparable in efficiency to a three-stage cyclone system. Therefore, the flue gas contains particles that are generally in the submicron to a few microns in size.

To protect the turbine, the gas conditioning device has to operate at about $1550^{\circ} \mathrm{F}$. A review of the literature indicates that a device that can operate at this temperature level is not commercially available. Recognizing the need for hot-gas cleanup devices for combustion turbines, DOE has funded programs with over ten organizations for research and development in this area.

*All references are included in Section 3 of this report. 


\subsection{EROSION}

Erosion results from abrasive wear caused by particulate impaction on the internal surfaces and, in general, is primarily a function of particle size, concentration, hardness, and velocity.

Particle concentration, size distribution, and chemical composition likely to be encountered in the glass furnace effluent have been characterized in Reference 2. In brief, the following characteristics were determined:

- Total particulate concentration averages about $0.106 \mathrm{gr} / \mathrm{scf}$ (200 ppm $w+$ )

- Highly abrasive particles (silica and alumina) represent about 18.5 wt percent of total particulate content

- More than 85 percent of the particulates are less than 2-um dia, and less than 1 percent exceeds $30-\mu \mathrm{m}$ dia

- The predominant solid material is sodium sulfate (63 wt percent)

A review of the literature on high-temperature, coal-fired gas turbine technology discloses that acceptable particulate loading levels for erosive wear are not well defined. No reliable correlations have been established between particle loadings and size distribution with turbine life expectancy. In addition, the limited information available is for axial flow turbines rather than the radial inflow design used in the Brayton-cycle system.

In general, many manufacturers conservatively limit the particle loading to $0.0002 \mathrm{gr} / \mathrm{scf}(0.4 \mathrm{ppm})$ for industrial applications; in addition, it is normally stipulated that turbines with inlet velocities between 1100 and 1200 fps should not ingest material greater than $5 \mu \mathrm{m}$ in size (Reference 3 ). Work sponsored by DOE under the high-temperature turbine technology program for coal gasification applications suggests maximum allowances of $0.002 \mathrm{gr} / \mathrm{scf}$ (4 ppm) for particulate loading and for material less than $6 \mu \mathrm{m}$ in effective diameter (Reference 4). Reference 4 notes that Australian experience with direct-firing of pulverized coal suggests that an axial-flow gas turbine might tolerate $0.05 \mathrm{gr} / \mathrm{scf}$ with particle diameters of 4-8 $\mu \mathrm{m}$ (no particle larger than $22 \mu \mathrm{m}$ ) and have at least $10,000 \mathrm{hr}$ of erosion endurance. A General Electric Company proprietary correlation (for pulverized coal boiler flyash) between particle size and erosion indicates that erosion drops off dramatically when particles are less than about $12 \mu \mathrm{m}$ in diameter and becomes negligible for particles less than about $9 \mu \mathrm{m}$ (Reference 5). Other references on fluidized bed combustor processes cited in Reference 5 indicate that particles less than $2 \mu \mathrm{m}$ will have a polishing rather than an erosive effect.

As a result of turbine blade testing at the Exxon miniplant (Reference 6), General Electric is reevaluating its particle specification for PFBC. The specification may permit essentially unlimited particle concentrations in the less than 2- $\mu \mathrm{m}$ range, very few in the larger than 10- $\mu \mathrm{m}$ range, and a more liberal quantity than previously allowed in the intermediate range. 
It has been AiResearch experience, particularly in radial inflow turbines used in air cycle air conditioning systems, that particules smaller than about $3 \mu \mathrm{m}$ do not cause erosion. Because most of the particles in the glass furnace effluent are less than $2 \mu \mathrm{m}$ in diameter, erosion damage was not expected. However, during the model subatmospheric system (SAS) tests (Reference 7) erosion of blade tips was evident in less than $20 \mathrm{hr}$ (Figure 1-1).

Transmission electron micrographs of the dust deposits in the nozzle showed a large degree of sintering, apparently the dust sinters and agglomerates into large enough particles to cause erosion damage. This unexpected result is probably because the gas temperature is equal $\left(1550^{\circ} \mathrm{F}\right)$ or close to the nominal melting point of the dust particles.

\subsection{DEPOSITION}

The model SAS turbocompressor test program has been completed and is reported separately (Reference 7). Extensive deposition of the flue dust in the nozzle occurred, even at temperatures well below the nominal design temperature of $1550^{\circ} \mathrm{F}$. Operation at off-design points and with a lower performance vaneless nozzle did not solve the fouling problem. A significant flow reduction occurred in only a few hours (Figures $1-2$ and $1-3$ ), causing the turbine performance to degrade and the compressor to operate in surge. The deposits were sintered and hard. Deposition and fouling of the turbine nozzle is thus a very serious problem in the SAS system.

Front face heat exchanger fouling is not a problem. However, when operating the heat exchanger in a SAS mode, with the required low flue gas exhaust temperatures, extensive fouling of the heat exchanger occurred in the back end. Sulfuric acid and water condenses and mixes with the flue dust, resulting in a tenacious hard deposit in the lower temperature back end of the core. The deposit could not be cleaned with an air lance and was highly corrosive to the metal (stainless type 409) used in the test heat exchanger.

When operating the test heat exchanger in the positive pressure system (PPS) mode, with a higher inlet and outlet temperature, all the dust deposits were easily removed by an air lance since there was no acid or water condensation.

Velocity at the vane inlet to the turbine was about $300 \mathrm{ft} / \mathrm{sec}$, and velocity at the throat was about $2700 \mathrm{ft} / \mathrm{sec}$. Using the bulk density of the powder $(0.225$ $\mathrm{gm} / \mathrm{cc}$ ), the maximum impact pressure range is (assuming no elasticity) 136 to 11,000 psi (actual particle density may be an order of magnitude greater). These potentially high impact pressures plus the stickiness due to the lower melting point temperature of various compounds or to eutectics in the dust could help cause the deposit/fouling problem found in the turbine.

Heat exchanger tests were also conducted and will be reported separately. It was found that the dust deposits on the heat exchanger front face were light and fluffy and were easily removed by an air lance in the plain fin configuration. The velocities were only 20 to $30 \mathrm{ft} / \mathrm{sec}$, resulting in an impact pressure two orders of magnitude less than the vane entrance and four orders of magnitude less than in the nozzle vane throat, where the hardest deposits were found. Gas velocity thus appears to be a very important factor in the fouling deposition of the flue dust in the test range of $1250^{\circ}$ to $1500^{\circ} \mathrm{F}$. 


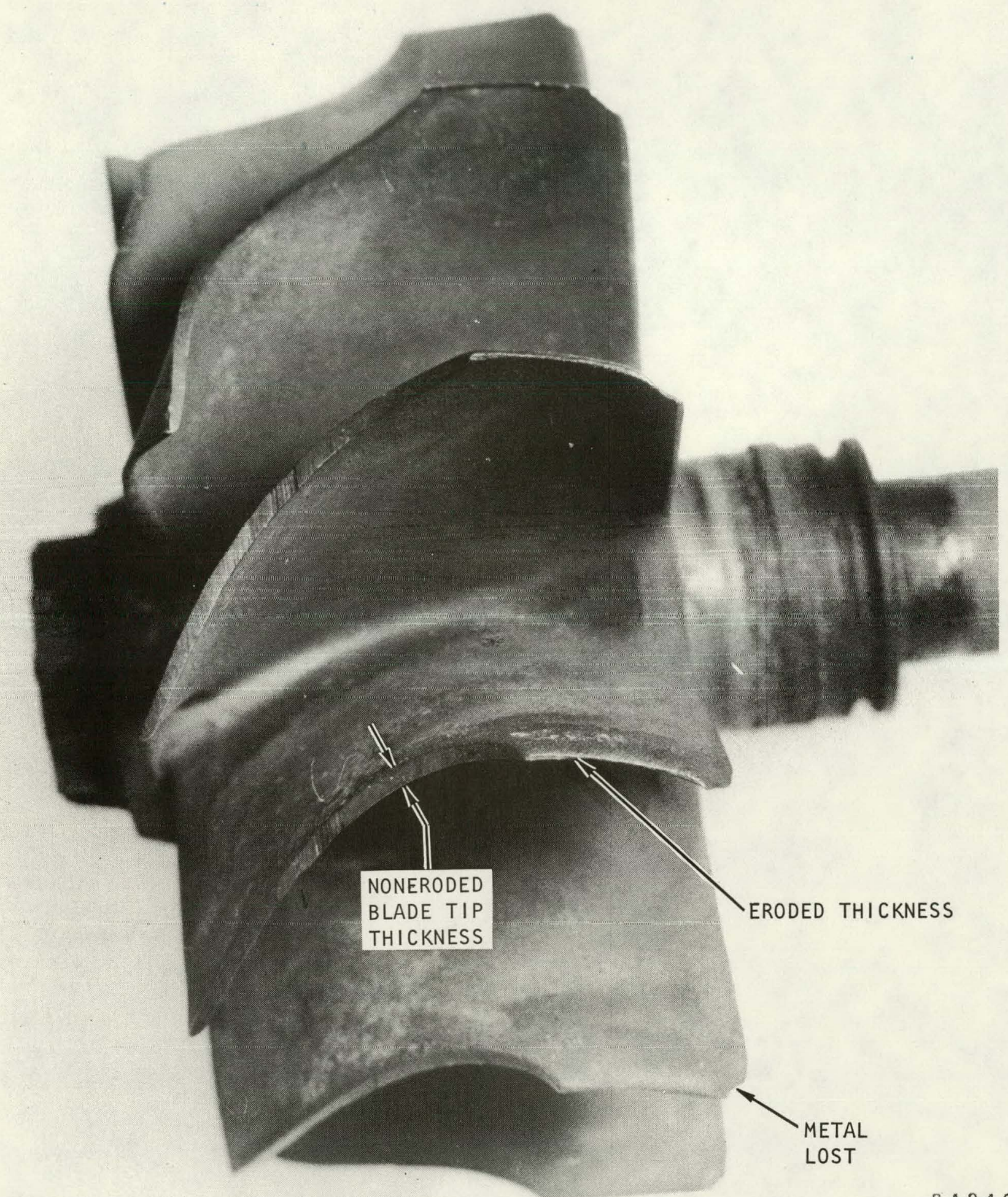

84842

Figure 1-1. Turbine Blade Tip Erosion

F-34721

80-17362, Rev. 1 Page 1-4 


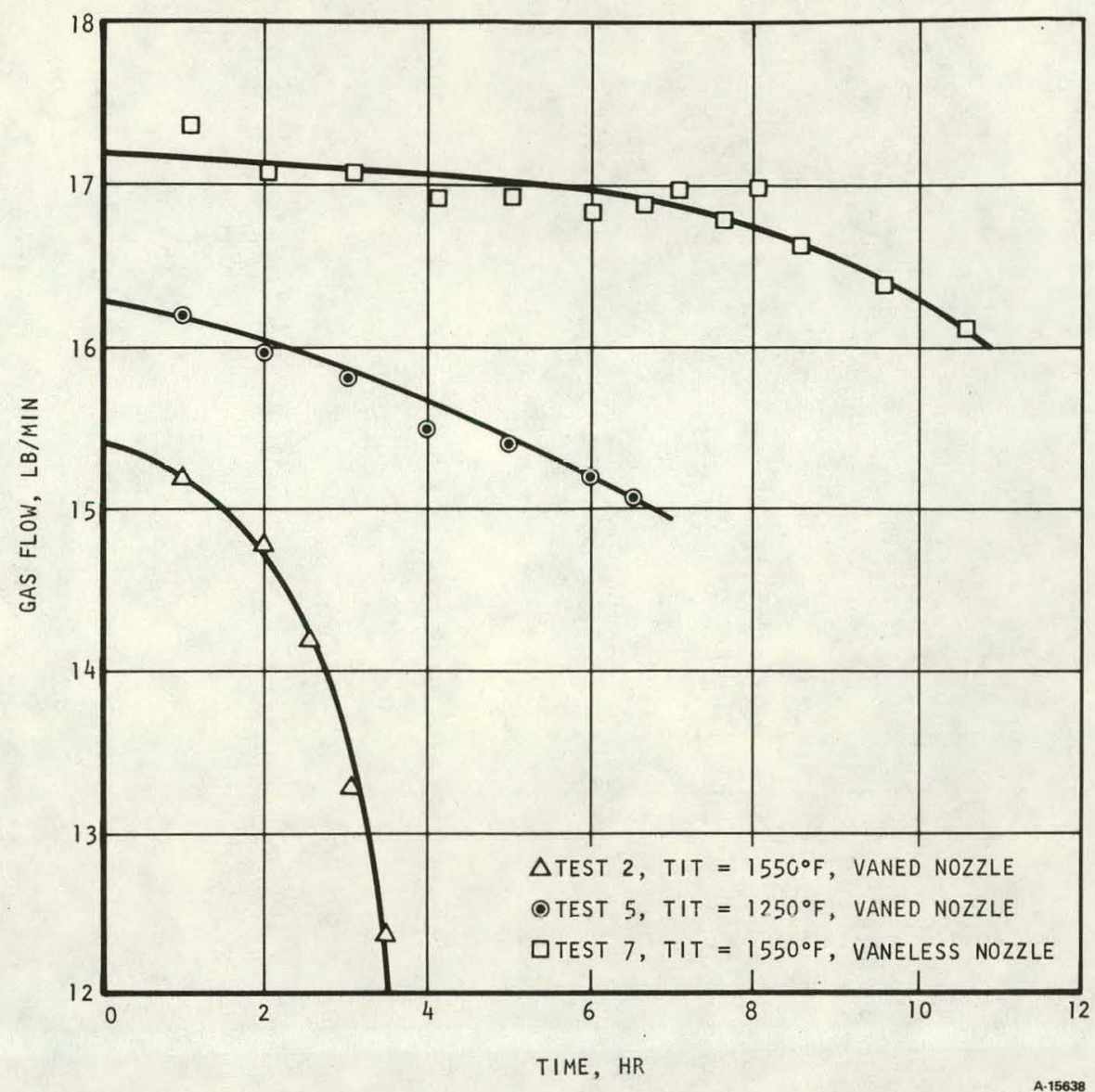

Figure 1-2. Flow Reduction in Model SAS Turbocompressor Tests

\subsection{CONCLUSIONS}

Based on the results of the model SAS turbocompressor tests, the flue dust from a glass plant causes extensive fouling of the turbine nozzle and erosion of the blade tips. To solve this problem for the SAS approach would require a gas conditioning system that would:

- Operate at $1500^{\circ} \mathrm{F}$

- Remove over 99 percent of the micron and submicron size dust particles in the flue gas to ensure satisfactory turbine life

- Be cleanable even though the dust particles are somewhat tacky at the operating temperature of the turbine

- Have long Iife and be cost effective 


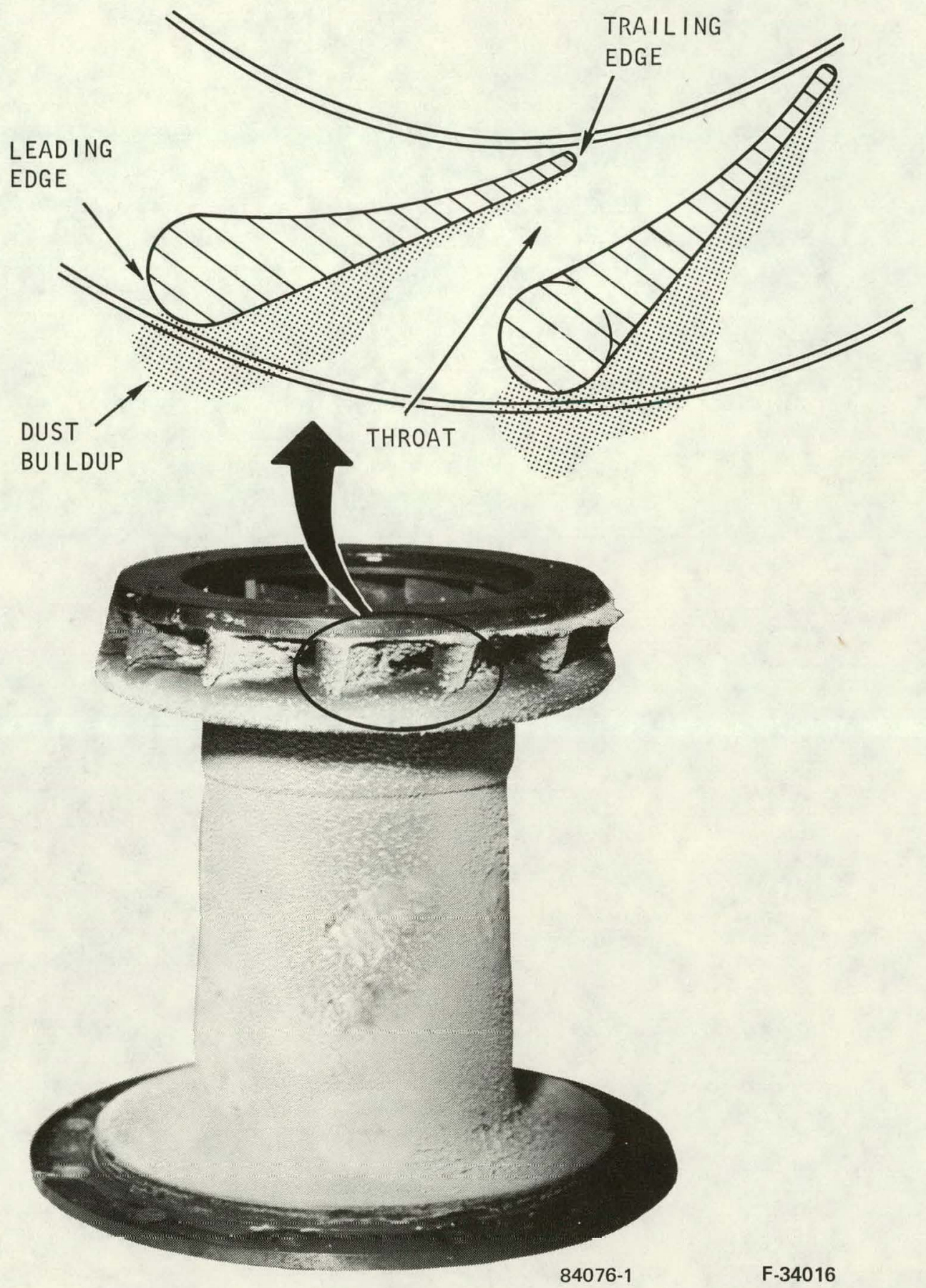

Figure 1-3. Nozzle Foul ing 
No commercial unit exists that can meet these requirements. In addition, even after extensive development for the PFBC programs, only the first requirement (operation at $1500^{\circ} \mathrm{F}$ ) has been solved. It is therefore concluded that a gas conditioning device for use with a SAS approach in a glass plant application is not feasible. In addition, the sulfuric acid and water that condenses in the heat exchanger in the SAS operational mode would still be a serious problem even if a gas conditioning device could be developed.

When operating the Brayton cycle in the PPS mode, flue gas does not pass through the turbine. Tests have shown that the PPS heat exchanger can be cleaned with an air lance, and a gas conditioning device is not necessary. Because the PPS provides essentially the same preheat and power as the SAS, with only one-third as many turbogenerator sets, the PPS approach without a gas conditioning device is preferable. 


\section{PARTICLE REMOVAL DEVICES}

A number of surveys, analyses, and data on particle removal at high temperatures and high pressures (HTHP) are available. Most of this work is associated with pressurized fluidized bed combustion (PFBC) of coal. However, there is little documented information available on units that were operated at high temperatures under controlled development tests, and except for cyclone separators, none of the units have been developed. The following discussion is intended to summarize the operating characteristics of various types of devices, as well as the current status of high-temperature devices with respect to their utilization in the Brayton cycle.

For the Brayton-cycle system, an important system consideration is the pressure drop of the removal device. The system operates at low pressure and power output and is quite sensitive to pressure drop as shown in Figure 2-1.

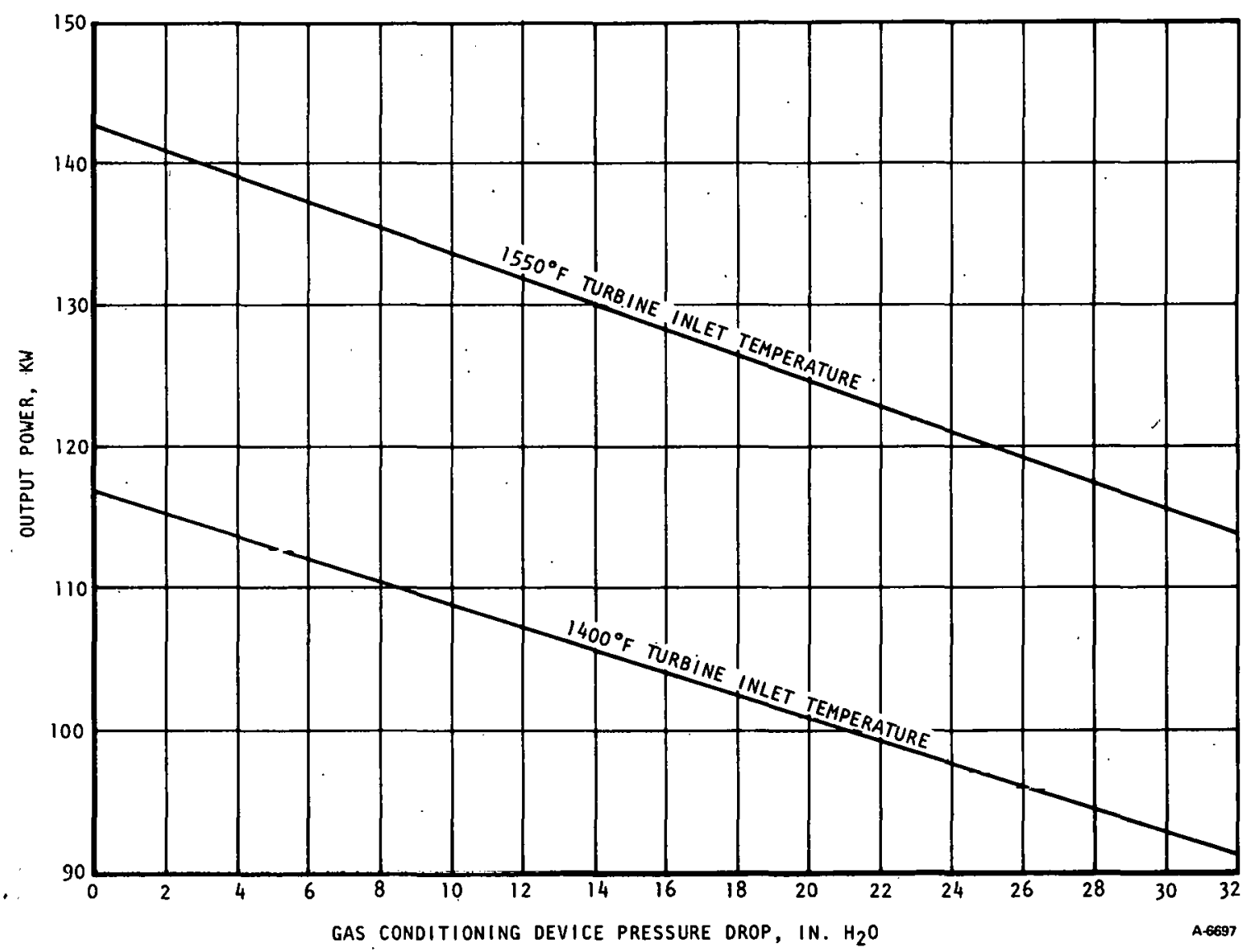

Figure 2-1. Gas Conditioning Device Pressure Drop, in. of Water 
Thus, for the Brayton-cycle application, the maximum pressure drop before cleaning should be relatively low--on the order of $10 \mathrm{in}$. $\mathrm{H}_{2} \mathrm{O}$ maximum. This corresponds to a power loss of about 7.5 percent.

Hot-gas particulate removal devices can be categorized as cyclones, granular bed filters, surface filters, electrostatic precipitators, and miscellaneous devices. All of these devices are discussed below.

\subsection{CYCLONES}

The main advantage in using cyclones for hot-gas cleanup is their simplicity (no moving parts) and their proven technology. Cyclones have been used for many years under high-temperature and high-pressure conditions in fluidized catalytic cracking units. A major disadvantage of conventional cyclones is their poor efficiency for removing $f$ ine particles of less than 5-um dia (Reference 8), although some high-efficiency designs attain up to 90-percent efficiency on particles of 2- to 3-jm dia. For PFBC, applications, the current approach is to use two or three conventional cyclones in series, followed by a positive filtration device such as a granular bed or ceramic fiber surface type filter.

The particle collection efficiency of cyclones improves with an increase in the following areas: particle density, particle diameter, gas inlet velocity, cyclone body length, number of turns made by the gas in the cyclone, ratio of cyclone body diameter to outlet diameter, and the smoothness of the inner wall. The efficiency decreases with an increase in gas viscosity, inlet duct width, inlet area, outlet diameter, cyclone diameter, and gas density (Reference 9).

The fact that the efficiency of a cyclone increases as its diameter decreases while maintaining constant inlet velocity has led to the development of multicyclones. A multicyclone unit comprises a large number of small cyclones manifolded together in a parallel flow arrangement. The individual cyclones, commonly called tubes, are often as small as 1.5 in. in diameter. These units offer better performance than a conventional cyclone of equal flow capacity in removing particles in the 1- to 10-um-dia range. However, smaller cyclones result in higher pressure drops.

In the Exxon miniplant program (Reference 6), a three-stage cyclone system that utilizes conventionally designed cyclones was tested over some 20 runs with a run duration of between 8 and $250 \mathrm{hr}$. Test results showed that material captured by the second-stage cyclone had a mass medium particle size of 20 to $25 \mathrm{um}$. The overall efficiency for this cyclone was about 95 percent. The material captured by the third-stage cyclone had a mass median size of 3 to $5 \mu \mathrm{m}$, and the overall efficiency was about 90 percent. The particulate concentration in the gas exiting the third cyclone was 0.013 to $0.066 \mathrm{gr} / \mathrm{scf}$ (24 to $123 \mathrm{ppm}$ ). The mass median size of the particulates in the discharge gas was 1 to $3 \mu \mathrm{m}$, as determined by a Coulter counter. Both the total efficiency and the fractional collection efficiency were much higher than expected, especially since the cyclone was designed according to classical handbook formulas. Exxon concluded that the performance levels achieved by the threestage cyclone system may not be sufficient to meet EPA standards, but may be 
sufficient to protect the gas turbine from serious erosion damage. The operating conditions for the third-stage cyclone were as follows:

$\begin{array}{ll}\text { Pressure } & 700 \mathrm{kPa}(101.5 \mathrm{psia}) \\ \text { Temperature } & 635^{\circ} \mathrm{C}\left(1175^{\circ} \mathrm{F}\right) \\ \text { Flow rate } & 14.6 \mathrm{Nm} / \mathrm{min}(516 \mathrm{scfm}) \\ \text { Inlet velocity } & 36 \mathrm{~m} / \mathrm{min}(118 \mathrm{fps}) \\ \text { Pressure drop } & 4 \mathrm{kPa}\left(16 \mathrm{in} . \mathrm{H}_{2} \mathrm{O}\right)\end{array}$

Although the performance was very good for a cyclone device, the outlet concentration and size are similar to the inlet conditions for the Brayton-cycle system. In addition, the pressure drop is unacceptable.

To improve collection efficiency of conventional cycles, a unit that introduces high-pressure secondary airflow to maintain high centrifugal action has been designed and developed; the Aerodyne Type $S$ and the Donaldson Tanjet cyclones are of this type.

An Aerodyne unit modified for HTHP application was tested by Westinghouse. For practical operation, a secondary gas flow that amounted to two-thirds of the primary flow had to be provided by using a portion of the dirty gas stream. The Westinghouse tests showed poor collection efficiency for particles of $5 \mu \mathrm{m}$ and less (Reference 8). Because of the high power penalty associated with the requirements for secondary air, as well as the poor efficiency for fine particle removal, Westinghouse elected to proceed with development of a gas cleanup system for their PFBC program, which included a series of two conventional cyclones and an in-house granular bed filter. Westinghouse also tested the Donaldson Tanjet cyclone and confirmed that the unit maintained its performance at high temperatures $\left(>1600^{\circ} \mathrm{F}\right)$. The test was conducted on a single Tanjet unit at $132 \mathrm{scfm}$ with a secondary flow of clean air at $15 \mathrm{scfm}$ and $33 \mathrm{psig.} \mathrm{Accord-}$ ing to Donaldson, the power requirement ranges from 4 to $7 \mathrm{hp}$ per $1000 \mathrm{scfm}$ of primary flow. The Tanjet program was discontinued by Donaldson to await the development of an attractive market (Reference 3 ).

Combustion Power Company used multicyclones (multiclones) in their CPU-400 pilot plant for testing solid-waste fuel. Three stages were used to meet air pollution standards and to protect the turbine from erosion. The first stage, known as the sand separator, collected coarse, solid-waste material in a settling chamber. Multiclones were used for the second. and third stages. The secondstage unit comprised forty-eight 6-in.-dia tubes, and the third-stage unit comprised one hundred 3.5-in.-dia tubes. The multiclones were prone to plugging in the lower cone body primarily due to suspected crossflow between the tubes. When plugging occurred efficiency decreased, allowing relatively large particles to enter the turbine and causing erosion of the stator blades after only a few hours of operation (Reference 9). Subsequently, the multiclone units were replaced with two stages of large-diameter (36- to 30-in.) cyclones. The inability of these large-diameter cyclones to meet the hot-gas cleaning requirements led to the in-house development of a granular bed filter. 
A summary of cyclone separators reviewed is presented in Table 2-1. Cyclones do not appear to be applicable to the Brayton-cycle system.

\subsection{GRANULAR BED FILTERS}

During the past few years, granular bed filters have received increasing attention because, in principle, they should achieve high collection efficiencies, are somewhat easier to clean than surface filters, and may be operated at high temperatures. These devices use sand, gravel, cake, or sintered material as the filtering media and operate on two basic removal mechanisms-filter cake formation and bed filtration (impaction). In general, designs that rely primarily on cake buildup exhibit higher collection efficiencies than those that are based on impaction as the primary removal mechanism. A summary of some granular bed filters is given in Table 2-2.

The Combustion Power Company has developed a crossflow, moving-bed granular filter. The granular material travels downward between the vertical walls of an annular filtering section placed inside a cyclone type housing. The vertical walls comprise louvered screens that allow the gas to pass through the moving granular bed in crossflow. Dirty gas is introduced tangentially into the cyclone type housing so that most of the larger particles are removed by centrifugal separation prior to entering the granular bed filter. The finer particles are removed by impaction as the gas flows through the bed. The filtered gas exits the unit by traveling up the hollow center of the annular section. Granules and dust continuously fall through a discharge cone at the bottom of the unit onto a vibrating screen. The dislodged particles pass through the screen into a dust container, while the cleaned granules are recirculated to the top of the annular section.

An 18,000-scfm unit intended to operate at $1600^{\circ} \mathrm{F}$ and 10 atm experienced structural failure (Reference 3). A second unit, which was designed for operation at $1200^{\circ} \mathrm{F}$ and $2 \mathrm{~atm}$ and for treating $10,000 \mathrm{scfm}$ at a loading not to exceed $4 \mathrm{gr} / \mathrm{scf}$, was delivered to the Morgantown Energy Research Center.

The Rexnord gravel-bed filter is commercially available but is not acceptable for operation in coal gasification processes (Reference 3). Most of the 150 Rexnord units are installed in cement plants and are reported to perform well at temperatures of up to $900^{\circ} \mathrm{F}$ (Reference 8 ). The Rexnord design combines both mechanical collection and gravel filtration in a single unit. The incoming dirty gas stream undergoes mechanical cycloning, which separates the bulk of material greater than $10 \mu \mathrm{m}$ in diameter. The gas then flows through an annular gravel bed where the finer particles are collected. The gas flow is reversed for cleaning, thus elutriating fines entralned in the gravel bed and collecting them in the cyclone section. During backflushing, the gravel bed is mechanically raked to enhance bed agitation. In addition to construction material limitations for hot-gas cleanup, the deagglomeration of ash that occurs during the backwash and raking cycles has actually increased the submicron content of the effluent stream above the inlet loading (Reference 3 ).

The Squires filter is of panel-bed construction, containing two grades of sand. The panel bed is constructed of two vertical louvered walls and an inner separating wall having closely spaced horizontal passages. The spaces formed 
TABLE 2-1

CYCLONE SUMMARY

\begin{tabular}{|c|c|c|c|c|c|c|c|}
\hline \multirow{3}{*}{$\begin{array}{l}\text { Manufacturer or } \\
\text { Developer }\end{array}$} & \multicolumn{2}{|c|}{ Operating Conditions } & \multirow{2}{*}{\multicolumn{2}{|c|}{$\begin{array}{l}\text { Removal } \\
\text { Efficiency* }\end{array}$}} & \multirow[b]{3}{*}{ status** } & \multirow[b]{3}{*}{ Reference } & \multirow[b]{3}{*}{ Remarks } \\
\hline & \multirow{2}{*}{$\begin{array}{l}\text { Demon- } \\
\text { strated } \\
{ }^{\circ} \mathrm{F} / \mathrm{atm}\end{array}$} & \multirow{2}{*}{$\begin{array}{l}\text { Projected } \\
\text { of/atm }\end{array}$} & & & & & \\
\hline & & & Percent & $\mu \mathrm{m}$ & & & \\
\hline Aerex Corp & $1200 / 5$ & -- & $\begin{array}{l}99.5 \\
23\end{array}$ & $>40$ & C & 3 & *** \\
\hline $\begin{array}{l}\text { Aerodyne } \\
\text { Development Corp. }\end{array}$ & $1600 / 5$ & $1800 / 10$ & $\begin{array}{l}95 \\
72\end{array}$ & $\begin{array}{l}8 \\
2\end{array}$ & C & 3 & Uses secondary air \\
\hline Donalfson Co., Inc. & $1800 / 5$ & --- & $\begin{array}{l}95 \\
76\end{array}$ & $\begin{array}{l}5 \\
2\end{array}$ & D & 3 & Uses secondary*** \\
\hline $\begin{array}{l}\text { Environmental } \\
\text { Elements Corp. }\end{array}$ & $700 / 10$ & $2100 / 10$ & $\begin{array}{l}99.9 \\
50\end{array}$ & $>19$ & C & 3 & Multicyclone ${ }^{* *}$ \\
\hline Exxon Corp. & $1175 / 6.9$ & -- & $\begin{array}{l}95 \\
85 \\
50\end{array}$ & $\begin{array}{l}>3 \\
>1.6 \\
>0.9\end{array}$ & D & 6 & $-\therefore$ \\
\hline $\begin{array}{l}\text { Fisher-Klorsterman, } \\
\text { Inc. }\end{array}$ & $80 C / 10$ & $1600 / 10$ & 95 & 5 & $\mathrm{C}$ & 3 & Projected efficiency \\
\hline Peer less Mfg. Co. & $1200 / 50$ & --- & $\begin{array}{l}100 \\
85\end{array}$ & 2 to 4 & C & 3 & Multicyclone $e^{* *}$ \\
\hline $\begin{array}{l}\text { Western } \\
\text { Precipitator Div., } \\
\text { Joy Mfg. Co. }\end{array}$ & $1150 / 4$ & -- & $\begin{array}{l}98 \\
50\end{array}$ & $\begin{array}{l}>10 \\
<10\end{array}$ & C & 3 & $\begin{array}{l}\text { Multicyclone; } \\
\text { efficiency data is } \\
\text { for } 450^{\circ} \mathrm{F}\end{array}$ \\
\hline
\end{tabular}

NOTES:

*Efficiency data for $600^{\circ} \mathrm{F}, 1$ atm

**For denonstrated operating conditions: $C=$ commercial, $D=$ developmental

***No reference temperature or pressure given for efficiency data 
TABLE 2-2

GRANULAR BED FILTERS

\begin{tabular}{|c|c|c|c|c|c|c|}
\hline \multirow[b]{2}{*}{$\begin{array}{l}\text { Manufacturer or } \\
\text { Developer }\end{array}$} & \multicolumn{2}{|c|}{ Operating Conditions } & \multirow[b]{2}{*}{ Removal Efficiency } & \multirow[b]{2}{*}{ Status* } & \multirow[b]{2}{*}{ Reference } & \multirow[b]{2}{*}{ Remarks } \\
\hline & $\begin{array}{c}\text { Demonstrated } \\
{ }^{\circ} \mathrm{F} / \mathrm{atm}\end{array}$ & $\begin{array}{l}\text { Projected } \\
\text { o } \mathrm{F} / \mathrm{atm}\end{array}$ & & & & \\
\hline Combustion Power Co. & $1600 / 1$ & $1600 / 2$ & $\begin{array}{l}85 \text { to } 97 \text { percent (no } \\
\text { particle size data } \\
\text { available) }\end{array}$ & D & 3 & $\begin{array}{l}\text { Moving bed; efficiency } \\
\text { data } 800^{\circ} \mathrm{F}, 1 \mathrm{~atm}\end{array}$ \\
\hline Ducon Co., Inc. & $900 / 2$ & $1600 / 10$ & $\begin{array}{l}85 \text { to } 98 \text { percient at } \\
700 \text { to } 900^{\circ} \mathrm{F}, 1 \text { to } \\
2 \text { atm (no particle } \\
\text { size data available) }\end{array}$ & D & 3 & $\begin{array}{l}\text { Extensive testing con- } \\
\text { ducted at Exxon mini- } \\
\text { plant proved unsuccessful }\end{array}$ \\
\hline $\begin{array}{l}\text { Rexnord Corporate } \\
\text { Research and } \\
\text { Development }\end{array}$ & $500 / 1$ & $1650 / 10$ & $\begin{array}{l}97.5 \text { percent, }>5 \mathrm{~m} \\
\text { at } 350^{\circ} \mathrm{F}, 1 \mathrm{~atm}\end{array}$ & C & 3 & $\begin{array}{l}\text { Includes integral } \\
\text { cyclone separator }\end{array}$ \\
\hline $\begin{array}{l}\text { Virginia Polytechnic } \\
\text { Institute }\end{array}$ & $1000 / 1$ & $2000 / \mathrm{high}$ & $\begin{array}{l}95 \text { to } 96 \text { percent at } \\
1000^{\circ} \mathrm{F} \text {, atm (no } \\
\text { particle size data } \\
\text { available) }\end{array}$ & $D$ & 3 & $\begin{array}{l}\text { Known as Squires panel } \\
\text { bed filter; current } \\
\text { development status } \\
\text { uncertain }\end{array}$ \\
\hline $\begin{array}{l}\text { Westinghouse Research } \\
\text { Labs }\end{array}$ & Ambient/1 & $1400 / 10$ & $\begin{array}{l}99 \text { percent, }>8 \mathrm{~m} \\
96.9 \text { percent, } 0 \text { to } \\
3 \mathrm{\mu m}\end{array}$ & D & 3 & $\begin{array}{l}\text { Efficiency data are for } \\
3 \text {-in. bed at ambient } \\
\text { conditions; development } \\
\text { work discontinued }\end{array}$ \\
\hline
\end{tabular}

*For demonstrated operating conditions: $C=$ commerical, $D=$ developmental 
between these walls are filled with the two grades of sand. Fine sand is used on the side exposed to dirty gas and provides a surface for cake formation. The coarse sand is used in the outlet side of the panel and serves as a baffle to contain the fine sand, thus eliminating the need for a metal screen. Four identical panels are joined along their vertical sides to form a long flue-like structure having a square cross section. This filter assembly is mounted inside a long vertical housing. The dirty gas inlet and the feed hopper for makeup sand are located at the top of the unit. The clean gas outlet is at the bottorn just above the dust removal chute. The filter is cleaned by a periodic blowback of gas that dislodges the cake buildup along with some sand and deposits them in a collecting hopper. A gravity feed arrangement replaces the sand lost by the blowback operation.

At ambient temperatures and atmospheric pressure, overall collection efficiencies on the order of 99.9 percent have been obtained in laboratory tests. In a high-temperature application $\left(1000^{\circ} \mathrm{F}\right)$ at the Morgantown Energy Research Center, overall collection efficiencies of 95 to 96 percent have been recorded (Reference 3). No filter cake buildup was observed.

The Ducon filter comprises a flat annular bed of granules held in place by circular channel walls with a screened bottom. A number of these bed elements are stacked vertically to make up the filter. Dirty gas enters the individual annular bed element horizontally through a screened opening around the outside top edge, makes a 90-deg turn, then flows downward through the granular. bed. The cleaned gas discharges from the screened bottom of the bed, executes another 90-deg turn, and passes into the inner cylindrical passageway formed by the stacked beds. A vertical gap between the screened bed bottom and top of the bed element below provides the exit path into the central passageway. When pressure drop across the beds reaches a predetermined level, a backflow of compressed air is introduced to fluidize the bed granules and expel the particles collected in the bed interstices. In contrast to types of granular bed filters described above, the Ducon filter is an extremely simple design with a fixed bed and no mechanical agitation devices or conveying systems.

Under fluidized catalytic cracker conditions $\left(700^{\circ}\right.$ to $900^{\circ} \mathrm{F}, 1$ to $\left.2 \mathrm{~atm}\right)$, the Ducon filter has achieved overall collection efficiencies of 85 to 98 percent for gas flows of 475 to $1000 \mathrm{scfm}$. The outlet gas loadings were consistently below $0.02 \mathrm{gr} / \mathrm{scf}$ (Reference 3 ). Collection efficiencies in terms of particle sizes were not available for these tests.

Pilot-scale testing conducted on the Ducon filter at the Exxon miniplant has been largely unsuccessful (Reference 6). Two Ducon units, each comprising five filter beds, were installed in parallel within a single large refractorylined pressure vessel following the second cyclone. Major problem areas that developed during the program that could not be corrected satisfactorily were:

(a) Low particulate outlet concentrations could not be maintained for more than a few hours

(b) Loss of filter media could not be prevented despite several design modifications

(c) Poor bed cleaning resulted in excessive pressure drops 
Although outlet particulate concentrations as $10 w$ as 0.07 to $0.11 \mathrm{~g} / \mathrm{Nm}^{3}$ ( 0.03 to $0.05 \mathrm{gr} / \mathrm{scf}$ ) were measured in several runs, the concentrations increased in all cases during the runs by as much as a factor of three in 8 to $10 \mathrm{hr}$. The poor removal efficiency and the increase in outlet particulate concentration with time have been attributed to poor dust removal from the beds during blowback cleaning cycles. It is suspected that sticky particles were present in the PFBC flue gas that could not be easily removed during blowback cleaning. A slight improvement in removal efficiency did occur when the frequency of the cleaning cycle was increased from one every $15 \mathrm{~min}$ to one every $4 \mathrm{~min}$; however, the outlet concentration still increased with time. It also has been suspected that some recycling of particulates from bed to bed may have occurred during blowback operation. It should be pointed out that outlet concentrations measured in these tests were consistently higher than those measured when a third-stage cyclone was used instead of the granular bed filter.

Initial tests were carried out using quartz granules of 250- to 600- $\mu$ m dia. in subsequent tests, 850- to 1400- $\mu \mathrm{m}$ alumina particles were used. A very dense iron oxide particle (speculite), ranging in size from 400 to $2000 \mu \mathrm{m}$, was also tested in an attempt to minimize filter media loss. The loss of filter media during blowback continued throughout the program and never was satisfactorily prevented. It should be noted that because of plugging experienced during earlier tests, the screen provided at the inlet opening in the original design was removed and other design modifications were made in an attempt to preclude the loss of filter media.

Poor bed cleaning also led to high-pressure drops across the filter. At the beginning of a run, the pressure drops were usually on the order of 14 to $20 \mathrm{kPa}$ ( 56 to $80 \mathrm{in}$. $\mathrm{H}_{2} \mathrm{O}$ ) after blowback, but increased to about 28 to $35 \mathrm{kPa}$ ( 113 to $141 \mathrm{in}$. $\mathrm{H}_{2} \mathrm{O}$ ) before blowback. After 8 to $15 \mathrm{hr}$ of operation, these pressure drops nearly doubled.

The Westinghouse granular bed filter is an experimental design in which the bed contains no metal internals (Reference 3). The unit comprises a rectangular tank, the bottom half of which is filled with a bed of sand spread over a deeper layer of coarse gravel used as bed support. A single perforated tube embedded in the coarse gravel, which lies horizontally and parallel to the long side of the tank, serves as the outlet for the cleaned gas. Fluidizing gas is admitted through a bank of perforated tubes embedded in the sand just above its interface with the coarse gravel. These tubes lie horizontally and parallel to the short side of the tank. A vertical tube centrally located in the top of the tank serves as the dirty gas inlet and fluidizing gas outlet.

Experimental units with 20- to 30-mesh 0ttawa sand 3 to 6 in. deep and $0.25 \mathrm{sq} f t$ in size have been tested under ambient conditions. Overall collection efficiencies were greater than 99 percent when tested with $4-i n$. bed depth and greater than 96 percent with $3-i n$. bed depth. In the particle size range of 0 to $0.3 \mu \mathrm{m}$, collection efficiencies were 100 percent and 96.9 percent, respectively, for bed depths of $4 \mathrm{in}$. and $3 \mathrm{in}$. A 7-sq $\mathrm{ft}$ unit was tested at $1100^{\circ} \mathrm{F}$ and atmospheric pressure, but testing was discontinued because of operating difficulties. 
No granular bed filter device is available for use in the Phase 1 portion of the Brayton-cycle program. Several advanced approaches, such as magnetic fluidized beds (Exxon), are being developed under DOE contracts.

\subsection{SURFACE FILTERS}

In the surface filters, gas particles flow through a porous media and are deposited in the voids on the upstream surface. The particles form a filter cake in the voids and aid the filtering process. Eventually, the pressure drop increases to a level that requires cleaning by backflow and/or pressure pulses. Usually, a small part of the filter cake is retained in the media during the cleaning process, which aids the normal filtering process. Fine mesh metal screens, porous metallic elements, synthetic textile fibers (for low-temperature applications), and ceramic fibers are used in surface filtration.

Metal filter media for high-temperature applications, such as in fluidized bed coal combustion, have not been selected for development. This is due to a number of engineering factors, including high pressure drop, rapid corrosion of the high surface area fine fibers, low face velocities, and cost. Ceramic fiber fabric and mats are the type of surface filters now receiving attention for high-temperature applications.

Fabric filters are widely used commerically at low temperatures for fine dust removal. With the development of continuous ceramic fiber yarn in small diameters $(10 \mu \mathrm{m})$, utilizing this fabric technology at high temperatures is becoming more teasible (Table 2-3). The fiber is woven into a fabric and made into long thin cylindrical bags that can be cleaned with pulses of compressed air. Typically, the pressure drop is low; 2 in. $\mathrm{H}_{2} \mathrm{O}$ after cleaning and increasing to 4 to $6 \mathrm{in}$. $\mathrm{H}_{2} \mathrm{O}$ before the next cleaning cycle. However, face velocity is quite low (in the order of $2 \mathrm{ft} / \mathrm{min}$ ), and large units are generally required.

The Buell Emission Control Division of Envirotech Corporation has developed a high-temperature fabric filter that has been tested in the Westinghouse fluidized bed facility under contract to EPRI (Reference 10). In tests at $800^{\circ}$ and $1500^{\circ} \mathrm{F}$, the filter pressure drop after cleaning was low $(0.1$ to 5 in. $\mathrm{H}_{2} \mathrm{O}$ ), and the recovery plateau pressure did not show an increasing trend during the 50-hr test period. Although this preliminary, short term test of a fiber fabric filter is encouraging, additional development testing is required to demonstrate material endurance and long-term stabilization of recovery pressure for use in PFBC operation.

For application to the Brayton cycle system, there are two main areas of concern. Although the filter efficiency was over 99 percent, the mass mean size of particles was $15 \mu \mathrm{m}$ and only 7 percent were less than $2 \mu \mathrm{m}$. As noted previously, the majority of flue gas particles are smaller than $2 \mu \mathrm{m}$. There apears to be a dropoff of efficiency below $2 \mu \mathrm{m}$. Because significan't flow reduction occurred in only a few hours, even if a 99 percent efficiency could be obtained with these very fine particles, fouling would still occur, and the turbine would have to be dismantled and cleaned of $f-l$ ine at periodic (i.e., month(y) intervals. In addition, the flue gas particles are at their nominal melting point of $1550^{\circ} \mathrm{F}$ (obtained from a differential thermal analysis test) and would have a much greater tendency to stick to the ceramic cloth than the particles used in the PFBC test, and thus the filter may not he cleanable. 
TABLE 2-3

SURFACE FILTERS

\begin{tabular}{|c|c|c|c|c|c|c|}
\hline \multirow[b]{2}{*}{$\begin{array}{l}\text { Manufacturer or } \\
\text { Developer }\end{array}$} & \multicolumn{2}{|c|}{ Operating Conditions } & \multirow[b]{2}{*}{ Removal Efficiency } & \multirow[b]{2}{*}{ Status: } & \multirow[b]{2}{*}{ Reference } & \multirow[b]{2}{*}{ Remarks } \\
\hline & $\begin{array}{l}\text { Demonstrated } \\
\text { }{ }^{\circ} \text { F/atm }\end{array}$ & $\begin{array}{l}\text { Projected } \\
{ }^{\circ} \mathrm{F} / \mathrm{atm}\end{array}$ & & & & \\
\hline Acurex Corp. & $15 \mathrm{CO} / 10$ & $1650 / 10$ & $\begin{array}{l}96 \text { to } 99.5 \text { percent, } \\
50 \text { percent }>3.5 \mu^{* *}\end{array}$ & D & 6,10 & $\begin{array}{l}\text { Saffil alumina mat insu- } \\
\text { lation material***. }\end{array}$ \\
\hline Brunswick Corp. & $70 \mathrm{C} /-$ & $1500 /-$ & $\begin{array}{l}99.5 \text { percent, } 0.5 \\
\text { to } 1.5 \mathrm{\mu m}\end{array}$ & D & 3 & $\begin{array}{l}\text { Efficiency data is for } \\
\text { ambient conditions; } \\
\text { stainless steel }\end{array}$ \\
\hline $\begin{array}{l}\text { Carbor undum Résearch } \\
\text { and Development Labs }\end{array}$ & $22 \mathrm{CO} /-$ & --- & -- & - & 3 & Boron nitride fiber \\
\hline $\begin{array}{l}\text { Envirotech Corp. } \\
\text { (Buell Division) }\end{array}$ & $15 C 0 / 10$ & --- & $\begin{array}{l}99.5 \text { percent, } \\
50 \text { percent }>15 . \mu \mathrm{m}\end{array}$ & $D$ & 10 & $\begin{array}{l}3 M \text { brand ceramic tibers, } \\
A B-312\end{array}$ \\
\hline Haveg Industries, Inc. & $25 \mathrm{CO} /-$ & --- & $\cdots$ & - & 3 & Refractory silica \\
\hline Hitco Materials Corp. & $18 \mathrm{C} 0 /-$ & -- & -- & - & 3 & Refractory silica \\
\hline JP Stevens Co. & $500 /-$ & $2000 /-$ & -- & - & 3 & Quartz fiber \\
\hline $\begin{array}{l}\text { Owens-Corning } \\
\text { Fiberglass Cor } p .\end{array}$ & $1200 /-$ & --- & --- & - & 3 & Silica fiber \\
\hline
\end{tabular}

NOTES:

*For demonstrated operating conditions: $C=$ commercial, $D=$ developmental

**Outlet particulates level too low for size distribution analys is with Coulter counter ***Compressed air blow back for cleaning 
Acurex Corporation has received several DOE contracts to develop a hightemperature ceramic filter. This device uses small diameter (3- $\mu \mathrm{m}$ nominal) ceramic (alumina) fibers. The filter media is in the form of a mat, with random distributed fibers; the mat (commercially known as Saffil) is used for high-temperature insulation. Screens on the inner and outer surfaces of the filter media contain the filter in place.

The Acurex mat filter has been tested by Exxon and at Westinghouse under an EPRI contract. Acurex has al so received a large hot-gas cleanup contract $(\$ 1.4 \mathrm{million})$ from DOE to further develop their ceramic mat filter, with testing planned in the Curtiss Wright fluidized bed system.

The mat filter has been tested at the Exxon PFBC miniplant (Reference 6). These tests were conducted for short periods of time (generally $6 \mathrm{hr}$ ) before the filter was changed. A 4-in.-dia by $18-i n .-l o n g(1.57 \mathrm{sq} f t$ of surface area) filter was used in a slipstream downstream of the miniplant second-stage cyclone separator. Nominal test conditions were:

$\begin{array}{ll}\text { Pressure } & 700 \mathrm{kPa}(101.5 \mathrm{psia}) \\ \text { Temperature } & 800^{\circ} \mathrm{C}\left(1472^{\circ} \mathrm{F}\right) \\ \text { Flow rate } & 1.5 \mathrm{~m} 3 / \mathrm{min}(53 \mathrm{cu} \mathrm{ft} / \mathrm{min}, .7 .5 \mathrm{lb} / \mathrm{min}) \\ \text { Inlet velocity } & 10.3 \mathrm{~m} / \mathrm{min}(0.56 \mathrm{ft} / \mathrm{sec}) \\ \text { Pressure drop } & (C l e a n) 2 \mathrm{kPa}\left(8 \mathrm{in} . \mathrm{H}_{2} \mathrm{O}\right) \\ \text { Inlet particle loading } & 0.9 \mathrm{~g} / \mathrm{m}^{3}(395 \mathrm{ppm})\end{array}$

With 50 percent of the particle loading less then $3.5 \mu \mathrm{m}$, removal efficiency was quite high, usually well over 90 percent.

In reviewing the Exxon miniplant data, there are two primary concerns in applying this approach to the Brayton-cycle system; one is the way the pressure drop increases rapidly, requiring frequent cleaning cycles, and the other is the reversibility of the cleaning process. In the Exxon tests, the tilters were cleaned every five minutes, resulting in an off-line time of 7.5 percent. This is a relatively high off-line time and can represent a large power requirement for cleaning. This may be alleviated by reducing the face velocity and increasing the size of the unit.

In all the runs at the Exxon plant, the pressure drop after cleaning increased with time and never reached a constant value. Typically, the pressure drop was still increasing at a high rate near the end of the relatively short test runs as shown in Figure 2-2. This may be the result of the cleaning cycle or may be due to irreversible plugging.

Westinghouse tests (Reference 10) with the Acurex mat filter al so showed high removal efficiency. However, the problems of high pressure drop and blinding of the filter due to fines driven deep into fibers of the filter and 


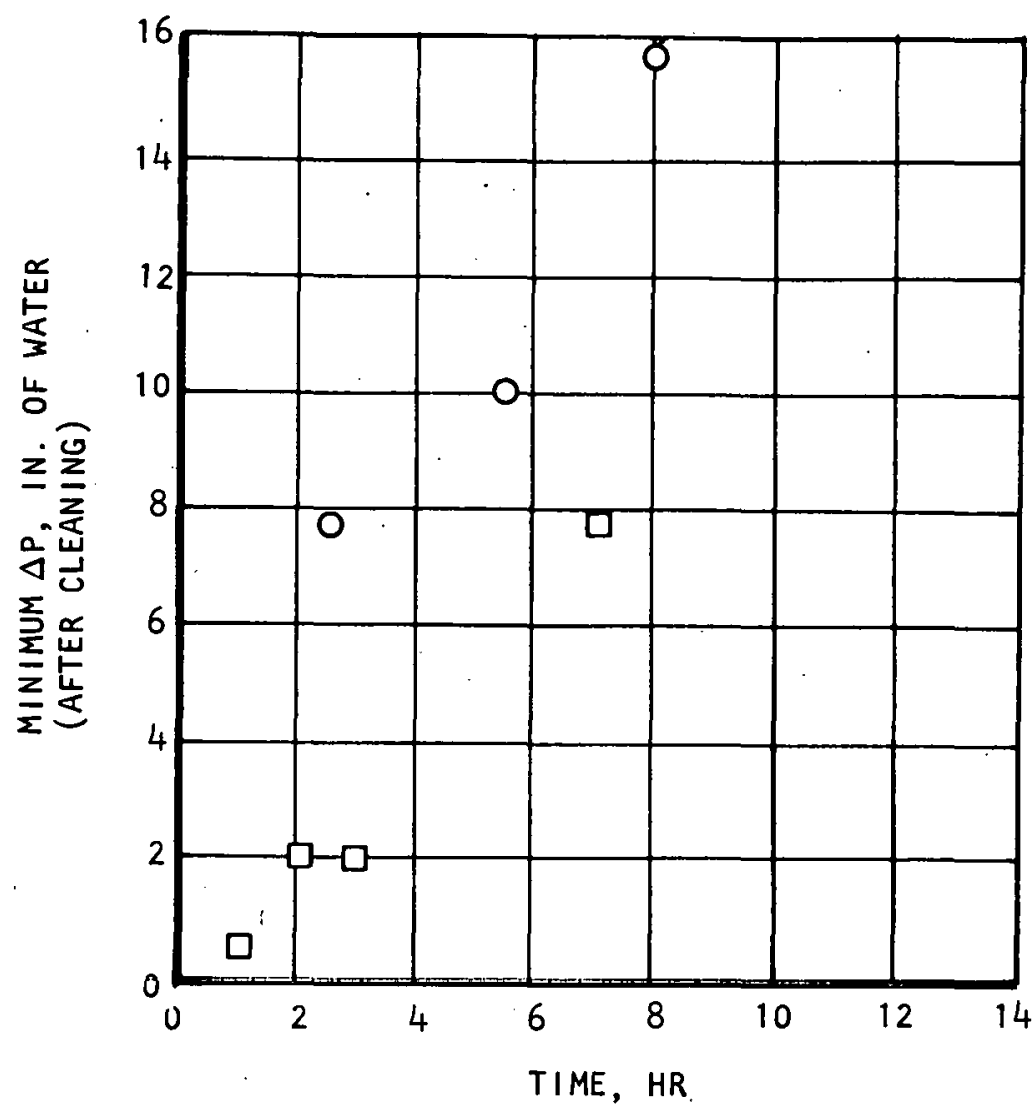

RUN N0. 89

O RUN NO. 91

Figure 2-2. Ceramic Mat Fiber Filter Data

not being driven out during cleaning were again evident as in the Exxon tests. The Westinghouse data (Figure 2-3) indicates that a recovery plateau pressure after cleaning was not established but rather that the pressure drop after cleaning continually increased indicating gross blinding or fouling of the mat filter. This serious problem would be further aggravated in the flue gas environment because of the much smaller particle size and its tendency to stick.

Based on the SAS and heat exchanger tests conducted at AiResearch, and the results of the Westinghouse PFBC tests, both the ceramic fiber fabric and mat fllter appruacles ale nut applicatle for use in a Brayton cycle SAS.

\subsection{ELECTROSTATIC PRECIPITATORS}

Electrostatic precipitators have been used for many years in industrial applications, including coal flyash collection by the utilities at moderate process conditions $\left(250^{\circ}\right.$ to $750^{\circ} \mathrm{F}$ at $1 \mathrm{~atm}$ to well below $\left.10 \mathrm{~atm}\right)$ where high collection efficiency of tine particulates $(<10 \mu \mathrm{m})$ is required. A low-temperature $\left(350^{\circ} \mathrm{F}\right)$ unit also has been used to remove particle matter from the flue gas of a glass container furnace. To date, little interest has been shown by industry in the development of these devices for HTHP applications. There are no electrostatic precipitators currently in operation at $1500^{\circ} \mathrm{F}$ and $300 \mathrm{psig}$; however, as the result of research studies, the limits of viable application have been extended to about $1700^{\circ} \mathrm{F}$ at low pressure and to gas pressures approaching 900 psia, but not concurrently (Reference 11). At atmospheric pressure such as for the glass plant, practical precipitation is limited to about $1100^{\circ} \mathrm{F}$. Thermal 

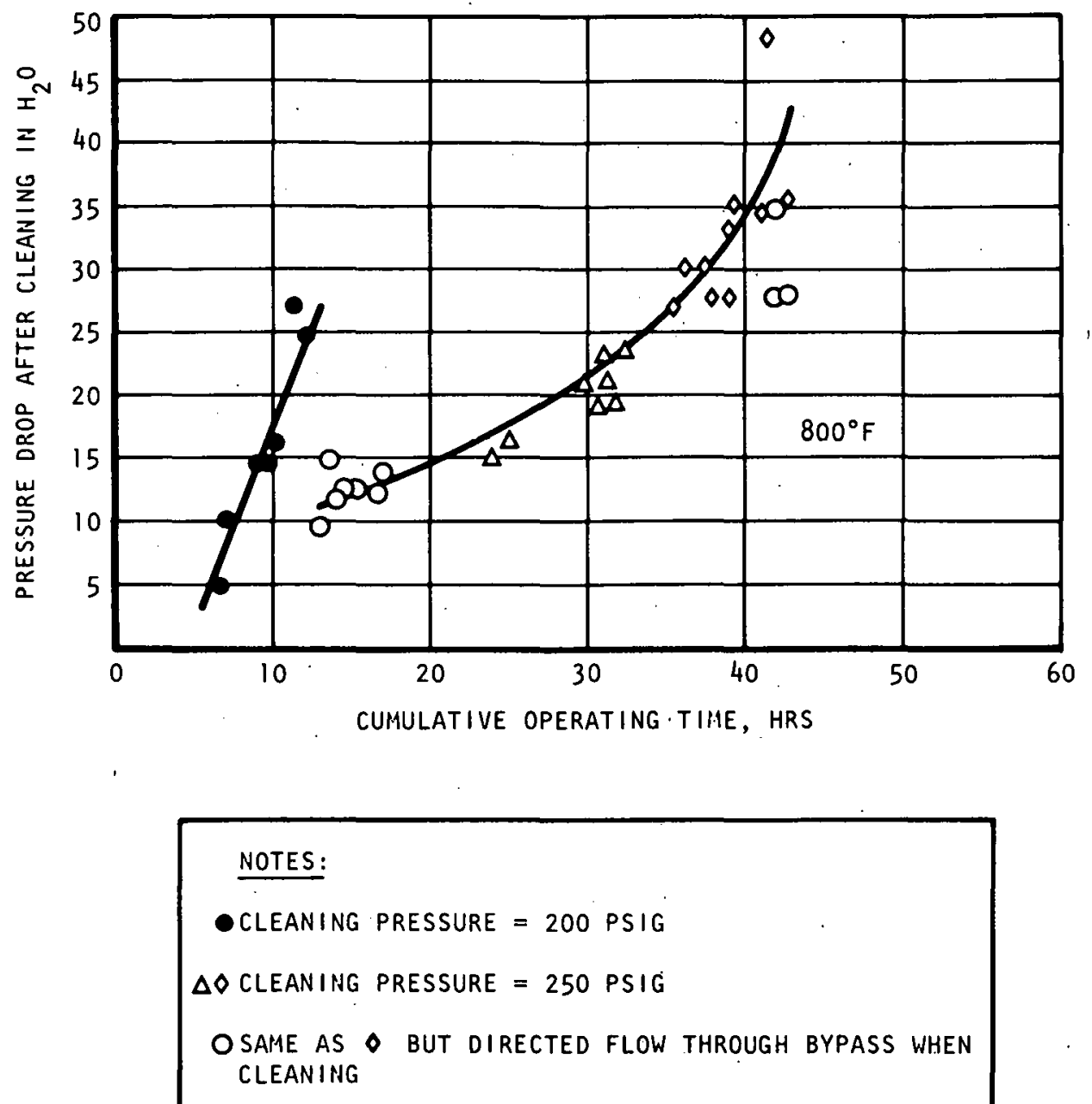

A.18051

Figure 2-3. Increasing Recovery Pressure After Cleaning

ionization effects limit high-temperature applications above $1500^{\circ} \mathrm{F}$. Presence of particles with low ionization potential, such as alkali metals, can increase currents in negative corona by significant amounts, thus limiting allowable operating voltages to lower levels. Other problem areas include the reentrainment of particles caused by the rapping of collecting electrodes during cleaning, the removal of potential sticky particulates, and material'selection and design to maintain good electrode alignment. The principal advantage offered by an electrostatic precipitator is its low pressure drop characteristic when compared with other types of filtration devices.

Development work for an electrostatic precipitator carried out by C. C. Shale at the Bureau of Mines in the mid-1960's showed that positive corona was more electrically stable than negative corona in the HTHP domain, although it 
was less efficient in particle removal. This research was terminated in the late 1960's after a semicommerical size unit had been built. C. C. Shale is presently associated with the Morgantown Energy Research Center.

Research-Cottrell designed and tested an experimental HTHP electrostatic precipitator for the Combustion Power Company's CPU-400 program that utilized fuel generated by incinerating municipal solid wastes. At gas conditions of $1700^{\circ} \mathrm{F}$ and $50 \mathrm{psig}$, positive polarity energization of the discharge electrode appeared superior to that of negative polarity in terms of voltage level that could be applied and electrical stability (Reference 9). However, precipitator performance, in removing alumina dust that was injected under controlled conditions with methanol fuel, showed negative polarity to be superior to positive polarity at conditions of $1650^{\circ} \mathrm{F}$ and $100 \mathrm{psig}$. Removal efficiencies ranged from 25 percent for positive polarity to as high as 87 percent for negative polarity. To investigate the effect of materials having low ionization potential on voltage corona current characteristics, potassium chloride salt in solution was injected with the fuel. Results indicated that potassium ion concentration levels of 333 to $400 \mathrm{ppm}$ by weight at $1700^{\circ} \mathrm{F}$ tripled the current measured for a given voltage when compared to noninjection.

Even though it was concluded that the use of electrostatic precipitation up to $1700^{\circ} \mathrm{F}$ and 100 psig was feasible, Combustion Power decided to develop a granular bed filter for final cleanup.

Available performance information for certain high-temperature electrostatic precipitators is summarized in Table 2-4.

\subsection{OTHER DEVICES}

The following paragraphs describe two nonconventional particulate removal devices that have potential applications for HTHP systems.

\subsubsection{Charged Filters (References 9 and 11)}

American Precision Industries, Inc. has developed a hybrid device called Apitron, which combines the principles of electrostatic precipitation and fabric filters. The device is essentially a wire-tube precipitator with a concentric bag filter and r.harged screen. The high-velocity precipitator functions as a prefilter and removes about 90 percent of all particles. The very fine particles are collected by the fabric filter at velocities four to five times higher than in conventional baghouses. These appear to have a significant size advantage over conventional precipitators and baghouses because of the considerably higher gas velocities. A $3000-\mathrm{cfm}$ pilot plant operating at $2000^{\circ} \mathrm{F}$ was successfully demonstrated on calcium sulfate dust at a cement plant. Efficiency of up to 99.98 percent was obtained with outlet dust loadings as low as $0.001 \mathrm{gr} / \mathrm{scf}$. It is not known how this device would perform at HTHP conditions.

\subsubsection{Molten Salt Scrubbers (References 3 and 9)}

Battelle Pacific Northwest Laboratories has constructed and tested an experimental scrubber with a 75-acfm flow capacity designed for operation at $1500^{\circ} \mathrm{F}$ and atmospheric pressure. The primary purpose of the scrubber was to 
TABLE 2-4

SUMMARY OF ELECTROSTATIC FRECIPITATORS

\begin{tabular}{|c|c|c|c|c|c|c|}
\hline \multirow[b]{2}{*}{$\begin{array}{l}\text { Manufacturer or } \\
\text { Developer }\end{array}$} & \multicolumn{2}{|c|}{ Operating Conditions } & \multirow[b]{2}{*}{ Removal Efficiency } & \multirow[b]{2}{*}{ Status* } & \multirow[b]{2}{*}{ Reference } & \multirow[b]{2}{*}{ Remarks } \\
\hline & $\begin{array}{l}\text { Demonstrated } \\
{ }^{\circ} \mathrm{F} / \mathrm{atm}\end{array}$ & $\begin{array}{l}\text { Projected } \\
{ }^{\circ} \mathrm{F} / \mathrm{atm}\end{array}$ & & & & \\
\hline $\begin{array}{l}\text { Electric Power } \\
\text { Research Institute }\end{array}$ & $1700 / \varepsilon$ & --- & --- & $\mathrm{D}$ & 3 & $\begin{array}{l}\text { Experimental unit was } \\
\text { scheduled for testing } \\
\text { in late } 1977\end{array}$ \\
\hline $\begin{array}{l}\text { Morgantown Energy } \\
\text { Research Center }\end{array}$ & $1470 / 7$ & --- & $\begin{array}{l}91 \text { to } 96 \text { percent } \\
\text { (no particle size } \\
\text { data available) }\end{array}$ & - & 3 & $\begin{array}{l}\text { Uses negative corona; lower } \\
\text { efficiencies with positive } \\
\text { corona }\end{array}$ \\
\hline Research-Cottrell & $2000 / 20$ & -- & --- & $D$ & 3 & $\begin{array}{l}\text { Feasibility for, HTHP appli- } \\
\text { cation established }\end{array}$ \\
\hline
\end{tabular}

*For demonstrated operating conditions: $C=$ commer $i c a l, D=$ developmental 
remove $\mathrm{H}_{2} \mathrm{~S}$ from hot fuel gases; particulate removal was only incidental. Molten alkali salts $\left(\mathrm{Na}_{2} \mathrm{CO}_{3}, \mathrm{~K}_{2} \mathrm{CO}_{3}, \mathrm{Li}_{2} \mathrm{CO}_{3}\right.$, and $\left.\mathrm{CaCO}_{3}\right)$ were used as scrubbing liquids in a vertically mounted, conventionally designed ventur i scrubber.

The experimental work at Battelle revealed the following problems:

- Overall collection efficiency was less than the expected 99 percent for all particles $4 \mu \mathrm{m}$ or larger.

- High corrosiveness of the scrubbing liquids presented difficult materials problems.

- Carryover of molten liquid droplets in the scrubbed gas was much greater than the allowable specifications. for gas turbine inlets.

- Molten salt reactions with other gaseous pollutants can potentially degrade the scrubbing liquid.

- Decomposition of the molten salts occur at temperatures around $1650^{\circ} \mathrm{F}\left(900^{\circ} \mathrm{C}\right)$.

- Insoluble particulate buildup necessitates the use of in-line filters in any regenerable scrubbing process.

- Energy requirements for molten scrubbers are estimated at 7 to 10 watts/cfm for collecting particles in the 0.5- to 2- $\mu \mathrm{m}$ range.

Because of the above problems and the fact that $\mathrm{H}_{2} \mathrm{~S}$ removal is not a concern, it is unlikely that molten salt scrubbing will be used for particulate control in fluidized-bed combustion. 


\section{REFERENCES}

1. "Brayton Cycle Heat Recovery System Characterization Program--Program Plan," AiResearch Report 79-16411, Rev. 3, May 30, 1980.

2. "Fl ue Gas Characterization Literature Search, Brayton Cycle Heat Recovery System Characterization Program," AiResearch Report 80-16900, March 1980.

3. Meyer, J. P. and M. S. Edwards, "Survey of Industrial Coal Conversion Equipment Capabilities: High-Temperature, High-Pressure Gas Pur ification," Oak Ridge National Laboratory report for the Department of Energy, ORNL/TM-6072, June 1978.

4. "Fuels $\mathrm{Cleanup}$ and Turbine Tolerance," High Temperature Turbine Technology Program, Phase I Program and System Definition, Topical Report: Generation Systems Division, Westinghouse Electric Corporation, Lester, Pennsylvania, for ERDA, FE-2290-27, February 1977.

5. "Advanced Clean-up Hardware Performance Guidel ines for Commercial Plant (Task 4.1.2)," CFCC Development Program, March 1978, General Electric Company Work Performance under DOE Contract No. EX-76-C-012357.

6. "Miniplant and Bench Studies of Pressurized Fluidized-Bed Coal Combustion: Final Report," Interagency Energy/Environment R\&D Program Report, EPA-600/7-80-013, January 1980.

7. "Brayton Cycle Heat Recovery System Characterization Program-Subatmospheric System Test Report," AiResearch Report 81-17949, July 1981 .

8. B. N. Murphy, et al, "Fuel Gas Cleanup Technology For Coal Gasification," Gilbert/Commonwealth Report FE-2220-15 for ERDA, March 24, 1977.

9. "Particulate Control for Pressurized Fluidized Bed Combustion," Gilbert/Commonwealth Report HCP/T2220-16 for DOE, May 1978.

10. "Evaluation of Ceramic Fiber Filters for Hot Glass Cleanup in Pressurized Fluidized-Bed Combustion Power Plants," Westinghouse Electric Corporation for Electric Power Research Institute, EPRI Report CS-1846, May 1981.

11. "Purification of Hot Fuel Gases From Coal or Heavy Oi I," Stone and Webster Engineering Corporation Inter im Report EPRI 243-1 for Electric Power Research Institute, November 1974. 